\title{
PREVALENCE AND CLINICOMYCOLOGICAL STUDIES OF OTOMYCOSIS: A REVIEW
}

\author{
KK Nipa ${ }^{1 \& 2}$, AHM Kamal ${ }^{3}$ and A Imtiaj ${ }^{*}$ \\ ${ }^{1}$ Shah Mukhdum Medical College, Rajshahi, Bangladesh \\ 2Institute of Biological Sciences, University of Rajshahi, Rajshahi-6205, Bangladesh \\ ${ }^{3}$ Rajshahi Medical College and Hospital, Rajshahi, Bangladesh \\ ${ }^{4}$ Department of Botany, University of Rajshahi, Rajshahi-6205, Bangladesh
}

\begin{abstract}
Otomycosis is a chronic ear disease of external auditory canal and it is more prevalent in warm, humid and dusty environment, although it is now found throughout the world. The most commonly found causative agents as of fungal species are Aspergillus and Candida along with preponderance of various fungal and bacterial species has also been reported. The aim of this review is to focus on the prevalence of causal agents of otomycosis in the global context and its clinical management. A total of 63 research articles have been reviewed, which deals prevalence of otomycosis. Its clinicomycological studies both separately and altogether with folk medicine in relation to treatment of otomycosis were also reviewed. Findings of various reports revealed that the Aspergillus and Candida species are the main causal agents of otomycosis. But many reports indicate that a few of other fungal species along with bacteria particularly Staplylococcus aureus and Pseudomonas aeruginosa are also responsible for accelerating this disease in human all over the world. In many reports, improper self-cleaning of ear has been found as major predisposing factor of otomycosis. This review suggests that health education, improvement of socioeconomic status and health caring facilities should be increased for reducing prevalence of otomycosis. However, more research needs to be carried out because of its severe parallel effects to the human health.
\end{abstract}

Key words: Causal organisms, Clinicomycology, Etiology, Otomycosis, Prevalence

\section{Introduction}

Otomycosis, also called fungal otitis externa is one of the frequently encountered fungal infections of external auditory canal (Agarwal and Devi 2017). This is commonly seen in tropical and subtropical regions of the world. The frequency to otomycosis depends upon different climatic conditions with higher prevalence in the hot, humid and dusty areas (Fasnula et al. 2008, Pontes et al. 2009, Pradhan et al. 2003). Review of the literature reveals otomycosis to be a common medical problem in India (Kaur et al. 2000, Viswanatha and Naseeruddin 2011, Viswanatha et al. 2012). So, in neighbuoring countries of India prevalence of otomycosis may be considered as frequently occurred fungal infection of external auditory canal (EAC) due to same tropical humid sort of environmental conditions. Particularly in Bangladesh perspective it may be said that no such study has been done to identify the causal agents of otomycosis. Literature also reveals that not much work has been conducted in this subcontinent. Thus, based on objective of the present study such as elucidation of predisposing factors, clinical presentations and mycological agents along with associated bacteria to be encountered in clinically diagnosed otomycosis cases, relevant literatures are reviewed here under three different subheads.

*Author for correspondence: aimtiajbot@ru.ac.bd 


\section{Prevalence of otomycosis}

Aspergillus niger and Candida albicans are more common causal agents offenders (Yassin et al. 1978, Paulose et al. 1989, Pontes et al. 2009, Viswanatha et al. 2012) with nearly sixty one fungal species being involved in external fungal otitis (Agarwal and Devi 2017). In their studies the microflora found in the EAC is comprised of a series of microorganisms viz. Staphylococcus aureus, S. epidermidis, Streptococcus, Micrococcus, Corynebacterium and Bacillus species as well as Pseudomonas aeruginosa, E. coli, Haemophillus influenzae, Moraxella catarrahalis etc. However, Mgbor and Gugnani (2001) stated that all commercial floras are not pathogenic as long as the balance between bacteria and fungi is maintained in EAC.

Agarwal and Devi (2017) made the highest prevalence of Aspergillus complex in cases of clinically diagnosed otomycosis in a reported rural community with higher practice of self cleaning, using home remedies, and eardrops to get relief from sensation of blocked ear and itching. They found male to female ratio among the participants was $1.3: 1.0$. Mycological examination yielded 346 fungal isolates in 310 samples from a total of 350 clinically diagnosed cases of otomycosis. In their study Aspergillus species was the predominat fungus followed by Candida species, Penicillium, Mucor and Trychophyton mentagrophyte. Only $11 \%$ of the cases were found to have mixed fungal-bacterial infections. Agarwal and Devi (2017) observed that self cleaning, instillation of mustard oil and use of ear drops appeared to be common predisposing factors in otomycosis.

Prasad et al. (2014) conducted an experiment on otomycosis in a rainy and humid coastal city of South India and identified the isolated organisms of otomycosis, which includ fungi and bacteria and also compared them with the normal ears. In their study instillation of coconut oil (42\%), use of tropical ear drops (20\%), and compulsive cleaning of external ear with hard objects (32\%) appeared to be the main predisposing factors in otomycosis. Aspergilli were found to be the most common isolates (80\%) followed by Penicillium (8\%), Candida albicans (4\%), Rhizopus (1\%) and Chrysoporium (1\%), the last one being reported for the first time in otomycosis. Among Aspergilli, A. niger complex (38\%) was the most common followed by A. fumigatus complex (27\%) and A. flavus complex (15\%). Bacterial isolates associated with fungi in otomycosis were $S$. aureus, $P$. aeruginosa and Proteus spp. If $42 \%$ healthy external ears fungi were also isolated. In conclusion, they predicted that otomycotic ears are often associated with bacterial isolates when compared to normal ears. Fungi are also present in a significant number of healthy external auditory canals and their profiles match with those of otomycosis.

The otomycosis results in inflammation, superficial epithelial exfoliation, masses of debris containing hyphae, suppuration and pain (Prasad et al. 2014). However, the incidence of otomycosis is reported to be high in tropical countries (Pontes et al. 2009, Fasunla et al. 2008, Pradhan et al. 2003, Munguia and Daniel 2008, Barati et al. 2011). The further study of interest will be conducted in Rajshahi city where, temperature fluctuate from $12^{\circ} \mathrm{C}$ (December-January) to $40^{\circ} \mathrm{C}$ (June-August) and monsoon prevails from June to September. Relative humidity is generally very high and saturation levels reach during the monsoon months. Incidence of otomycosis becomes high in the month of July-August compare to that of February-March. Age, sex and occupation are found to be more common factors among young man (Pradhan et al. 2003, Kaur et 
al. 2000, Viswanatha et al. 2012). In case of females also otomycosis have been reported by Pontes et al. (2009), Fasunla et al. (2008), Barati et al. (2011), Aneja et al. (2010) and Lia et al. (2012), although prevalence of this disease was proportionately found somewhat low in female patient.

Thakur et al. (2015) investigated the prevalence of otitis media and pattern of otological diseases in school going children of the Sunsuri district of eastern Nepal. Their findings revealed ear wax 541 (25.14\%) and chronic supportive otitis media $70(3.26 \%)$ as the commonest diseases. They further stated that otitis media with effusion (OME) $24(1.11 \%)$, acute otitis media (AOM) $18(0.84 \%)$, otomycosis $50(2.32 \%)$, otitis externa $13(0.6 \%)$, perichondritis $2(0.09 \%)$, sensational hearing loss $(\mathrm{SNHL}) 4(0.19 \%)$ and eustachian tube dysfunction (ETD) $9(0.42 \%)$ were found in their investigation. They suggested that health education, improvement of socioeconomic status and health care facilities will be helpful in reducing the prevalence of otological diseases.

Ear diseases in children are a major public health problem in developing countries (Thakur et al. (2015) and all the times it is a considerable burden. Adhikari et al. (2008) reported a high (60.6\%) prevalence of ear wax in school going children in Kathmandu valley of Nepal. In a study done by Chadha et al. (2012) in northern India, the prevalence of impacted wax was $7.93 \%$ in school going children aged 5-12 years. Otomycosis, otitis externa, perichondritis and sensorineural hearing loss are gradually increasing in developing countries due to poor improvement of socioeconomic status and lack of health care facilities and in majority of the cases patients or their guardians receive no attention to treatment.

Etiological agents of otomycosis in the north-western area of Iran were determined by Kazemi et al. (2015). They determined the local epidemiologic pattern of otomycosis. In their study otomycosis was diagnosed in 129 cases with the highest prevalent of cases occurring in male subjects between 21-40 years of age. From an etiological point of view, 116 patients were infected by saprophytic mold and 09 patients were infected by yeast. Three cases involved dermatophytes, and in one case the subject was infected with Eurotium (the perfect stage of $A$. niger). It was the most common mold followed by $A$. flavus, $A$. fumigatus, Penicillium spp., Fusarium spp. and Rhizopus spp. Belonging to the genus Candida, $C$. albicans and $C$. tropicallis were also identified. Their study showed a high prevalence of otomycosis in the said area of Iran. Generally it is said that otomycosis is more prevalent in tropical and sub-tropical countries because of high humidity, hot weather and presence of dust in the invironment. But otomycosis studies in patients with suspected mycosis have been conducted in many different countries like USA (Jackman et al. 2005, Spain (Gutierrez 2005), Bahrain (Paulose et al. 1989), Brazil (Zaror et al. 1991), Turkey (Ozcan et al. 2003), Slovakia (Dorko et al. 2004), French (Yavo et al. 2004), Nigeria (Ologe and Nwabuisi 2002). The findings from these studies along with the results obtained from tropical and subtropical countries indicate that otomycosis has a global prevalence. Kazemi et al. (2015) found higher incidence of otomycosis in males, who were mainly agricultural workers and were of low socio economic status. On the other hand, the findings obtained by Aneja et al. (2010) were different in terms of gender. They found that the prevalence of otomycosis was higher in females than males in eastern part of Haryana, India. Various casual agents of otomycosis as reported by different research workers over the last few decades are tabulated here (Table 1a \& b) following Prasad et al. (2014). This comparative table reveals that apart from otomycosis, Aspergilli caused a broad 
spectrum of infections, and all the three species of Aspergillus have overlapping morphological characteristics. A few other fungal species have important role for causing otomycosis. Remarkably, Candida spp. was also found more common when compared to Aspergillus spp.

Table 1a. Frequency (\%) of various causal agents of otomycosis reported by different researchers of India (following style and content of Prasad et al. 2014).

\begin{tabular}{|c|c|c|c|c|c|c|c|c|}
\hline \multirow[b]{2}{*}{ Causal organisms } & \multicolumn{8}{|c|}{ Authors (India) } \\
\hline & $\begin{array}{c}\text { Joy } \\
\text { et al. } \\
(1980)\end{array}$ & $\begin{array}{c}\text { Jain and } \\
\text { Agrawal } \\
(1992)\end{array}$ & $\begin{array}{l}\text { Jaiswal } \\
(1990)\end{array}$ & $\begin{array}{l}\text { Kaur } \\
\text { et al. } \\
(2000)\end{array}$ & $\begin{array}{c}\text { Pradhan } \\
\text { et al. } \\
\text { (2003) }\end{array}$ & $\begin{array}{c}\text { Viswanatha } \\
\text { et al. } \\
\text { (2012) }\end{array}$ & $\begin{array}{c}\text { Prasad } \\
\text { et al. } \\
(2014)\end{array}$ & $\begin{array}{l}\text { Kulal } \\
\text { et al. } \\
(2017)\end{array}$ \\
\hline Aspergillus niger & 44.3 & 56.3 & 34 & 36.9 & 25.5 & 56 & 38 & 49.63 \\
\hline A. fumigatus & 15.7 & 15.6 & - & 41.1 & 6.6 & 18 & 27 & 48 \\
\hline A. flavus & 23.2 & 4.7 & - & 1.4 & 37.7 & - & 14 & 9.63 \\
\hline Other aspergilli & - & 3.1 & - & - & 0.9 & - & - & 0.74 \\
\hline Candida sp. & 7.6 & 6.3 & 46 & 13.7 & 10.4 & 16 & 4 & 34.82 \\
\hline Mucor sp. & 5.4 & 6.3 & - & 1.4 & - & - & - & - \\
\hline Penicillium sp. & 1.1 & 4.7 & - & 1.4 & - & 10 & 8 & 2.22 \\
\hline Rhizopus & - & - & 12 & 2.7 & - & - & 1 & - \\
\hline Chrysosporium sp. & - & - & - & - & - & - & 1 & - \\
\hline $\begin{array}{l}\text { Other fungi/ mixed } \\
\text { fungi }\end{array}$ & 2.7 & 3 & 8 & 1.4 & - & - & - & 1.48 \\
\hline
\end{tabular}


Table $1 b$. Frequency (\%) of various causal agents of otomycosis reported by different researchers from other than India (following style and content of Prasad et al. 2014)

\begin{tabular}{|c|c|c|c|c|c|c|c|c|c|c|c|}
\hline \multirow{3}{*}{ Causal organism } & \multicolumn{11}{|c|}{ Authors (Other than India) } \\
\hline & UK & S. Arabia & Iraq & I. coast & Slovakia & Nigeria & Brazil & Spain & China & Iran & Iran \\
\hline & Geaney & Yassin et al. & Yehia et al. & Yavo et al. & Dorko et al. & Fasunla et al. & Pontes et al. & G. Agndo et al. & Lia et al. & Barati et al. & Kazemi et al. \\
\hline A. niger & $\begin{array}{c}(1967) \\
13.2\end{array}$ & $\begin{array}{c}(1978) \\
51.2\end{array}$ & $\begin{array}{c}(1990) \\
70.1\end{array}$ & $\begin{array}{c}(2004) \\
20.3\end{array}$ & $\begin{array}{c}(2004) \\
-\end{array}$ & $\begin{array}{l}(2008) \\
48.35\end{array}$ & $\begin{array}{c}(2009) \\
20\end{array}$ & $\begin{array}{c}\text { (2011) } \\
35.9\end{array}$ & $\begin{array}{r}\text { (2012) } \\
54.77\end{array}$ & $\begin{array}{c}\text { (2011) } \\
41.6\end{array}$ & $\begin{array}{c}(2015) \\
62.9\end{array}$ \\
\hline A. fumigatus & 7.5 & - & 5.6 & 19.00 & - & 33.96 & 5 & 12.5 & 2.61 & 5.5 & 9.5 \\
\hline A. flavus & 9.2 & 18.3 & 15.6 & 16.00 & - & 5.43 & 10 & 42.4 & 6.09 & 49 & 20.7 \\
\hline A. candidus & - & - & - & - & - & - & - & 1.6 & - & - & - \\
\hline E. coli & - & - & - & - & 1 & - & - & - & - & - & - \\
\hline Candida sp. & 35.2 & 4.6 & 7.3 & - & - & 12.26 & 55 & - & 24.35 & 7.6 & 7.1 \\
\hline C. albicans & - & - & - & 20.9 & 52.5 & - & - & - & - & - & - \\
\hline C. parapsilosis & - & - & - & - & 27.5 & - & - & - & - & - & - \\
\hline C. tropicalis & - & - & - & - & 7.5 & - & - & - & - & - & - \\
\hline Protius mirabilis & - & - & - & - & 3 & - & - & - & - & - & - \\
\hline P. aeroginosa & - & - & - & - & 3 & - & - & - & - & - & - \\
\hline Haemophillus influesae & & - & - & & 1 & & - & - & - & & - \\
\hline Mucor sp. & - & 2.3 & - & - & - & - & - & - & - & - & - \\
\hline Penicillium sp. & - & 5.3 & - & - & - & - & - & - & - & - & 3.4 \\
\hline Rhizopus & - & - & 0.6 & - & - & - & - & 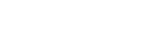 & - & - & 0.8 \\
\hline Chrysosporium sp. & - & - & - & - & - & 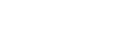 & - & 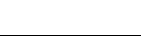 & - & - & - \\
\hline Sataphyloroccus epidermis & - & - & - & - & 31 & - & - & - & - & - & - \\
\hline S. aureus & - & - & - & - & 16 & - & - & - & - & - & - \\
\hline Paecilomyces variotii & - & - & - & - & - & - & - & - & - & - & - \\
\hline Other fungi/ mixed fungi & - & 4.6 & - & - & - & - & 10 & - & 2.61 & 0.9 & 4.8 \\
\hline
\end{tabular}


Fungi causing otomycosis and the associated bacterial pathogens were determined by Kulal et al. (2017). In the study of 150 samples, $51.3 \%$ yielded only fungal growth, $23.3 \%$ grew bacteria only and $19.3 \%$ showed mixed growth of fungi and bacteria. This research is conducted at K.V.G Medical College Hospital, Sullia D.K. Karnataka. Regarding culture positivity their findings varied compare to those of Deshmukh et al. (2014) and Panchal et al. (2013). However the studied area by Kulal et al. (2017) is of higher incidence of otomycosis. In this area hot and humid weather prevails throughout the year and heavy rainfall during monsoon (Prasad et al. 2014). The various bacteria isolated by Kulal et al. (2017) are depicted in Table 2. Their findings (Table 3 ) on fungus and bacterial cultures of 150 samples revealed a remarkable association as well as separate presence as causal agents of otomycosis. From their findings it may be said that otomycosis is mostly unilateral and manipulation of external ear with any hard objects may be the main reason for fungal growth in auditory canal. As causal agents of otomycosis particularly Aspergillus spp. and Candida spp. along with two bacterial species, S. aureus and Pseudomonas spp. are commonly responsible.

Table 2. Bacterial isolates grown among study group (after Kulal et al. 2017)

\begin{tabular}{lcc}
\hline Bacteria & Total number & Percentage (\%) \\
\hline Staphylococcus aureus & 21 & 29.17 \\
\hline Pseudomonas spp. & 20 & 27.78 \\
\hline CONS & 14 & 19.45 \\
\hline Klebsiella spp. & 07 & 9.72 \\
\hline Proteus spp. & 03 & 4.17 \\
\hline Escherichia coli & 03 & 4.17 \\
\hline Enterobacter spp. & 02 & 2.78 \\
\hline Citrobacter spp. & 01 & 1.38 \\
\hline Morganella spp. & 01 & 1.38 \\
\hline Total & 72 & 100 \\
\hline
\end{tabular}

CONS: Coagulase Negative Staphylococci (The Staphylococci species which does not give positive result to coagulase test). 
Table 3. Number of fungi and bacteria isolated from the study group (after Kulal et al. 2017).

\begin{tabular}{clcc}
\hline Number of cases & Type of growth & Fungi & Bacteria \\
\hline 58 & Single fungus & 58 & - \\
\hline 19 & Two fungi & 38 & - \\
\hline 16 & One fungus, one bacterium & 16 & 16 \\
\hline 06 & Two fungi, one bacterium & 12 & 06 \\
\hline 04 & One fungus, two bacteria & 04 & 08 \\
\hline 02 & Two fungi, two bacteria & 04 & 04 \\
\hline 01 & Three fungi, one bacterium & 03 & 01 \\
\hline 33 & Single bacterium & - & 33 \\
\hline 02 & Two bacteria & - & 04 \\
\hline 141 & Total & 135 & 72 \\
\hline 09 & No growth & - & - \\
\hline
\end{tabular}

\section{Clinicomycological studies}

Otomycosis can be diagnosed clinically on the basis of symptoms like pruritus, otalgia, discharge, blockage, hearing loss and presence of musky debris resembling wet news paper in the external audiroty meatus (Mgbe et al. 2010). They observed that otomycosis was predominantly unilateral with both ears almost equally affected. Their study highlighted a management challenge in the treatment of otomycosis in Calabar, South-South Nigeria. The fungal species causing the disease in their center could not be established due to lack of poor access to mycological facilities. However, they stated that cure rates following antifungal treatment was high (86\%) even in the absence of mycological identification of causative fungal agent. They used the drugs like Ciloquinone/ Flumethasone (eardrops/cream), Beclomethasone dipropionate/ Clotrimazole/ Lidocaine hydrochloride (eardrops) or Gentian violet as indespensible tropical agents in management of otomycosis. Although their diagnosis and treatment was presumptive based on clinical symptoms and signs, their attempts and success were found in agreement with the reports of Kaur et al. (2000), Tang et al. (2006) and Paulose et al. (1989).

The fungal agents responsible for this clinical entity are found as saprophytes in the environment (Sarvan et al. 2012). Otomycosis occurs worldwide but it is more common in tropical and subtropical zones and more prevalent in monsoon season. In recent years fungal infections have gained more importance in medicine because of the large number of immuno-compromised patients. According to Jadhav et al. (2003) such fungi may also produce infections in immuno-competent hosts. In this type of patients, treatment of otomycosis should be vigorous to prevent complications such as hearing loss and invasive temporal bone infection (Rutt and Sataloff, 2008). Some bacteria can cause disease with similar symptoms like the fungal agent and thus, confirming the appropriate etiology, which is more important for proper treatment (Ahmad et al. 2009). 
Philip et al. (2013) studied effectiveness of 7.5\% Povidone lodine in comparison to $1 \%$ Clotrimazole with Lignocaine in the treatment of otomycosis. Their objective was also to identify the most common fungal isolate in their collected population. They conducted a single blinded prospective longitudinal study over a period of 12 months in a tertiary referral center. Thirty four (34) patients in age group of 15-70 years clinically diagnosed with otomycosis were included in their experiment. These individuals were divided into two groups selected randomly. One arm received 75\% Povidone lodine otic drops and the other 1\% Clotrimazole and lignocaine drops. Evaluation was based on resolution of symptoms and signs after treatment. Both arms showed improvements which were comparable, thus suggesting the role of Povidone iodine in the management of otomycosis. Table 4 and 5 in this review given by Philip et al. (2013) in their article reveals that povidone iodine is an effective antifungal in the treatment of otomycosis. On examination after 2 weeks of treatment, no spores were encountered. They emphasized meticulous aural toileting, especially in the region of the isthmus and the anterior reces. However, a very few studies have described sex and age distributions, and the affected individuals mainly belonged to the 30-40 years age groups (Ozcan et al. 2003, Yassin et al. 1978). The above mentioned experiment suggests that application of povidone iodine is much useful in clinically diagnosed cases of otomycosis in human's supportive otitis media.

Table 4. Symptom resolution with povidone-iodine and clotrimazole (after Philip et al. 2013)

\begin{tabular}{|c|c|c|c|c|c|c|}
\hline \multirow{3}{*}{ Variables } & & \multicolumn{4}{|c|}{ Drug } & \multirow{3}{*}{$P$ value } \\
\hline & & \multicolumn{2}{|c|}{ Clotrimazole + lignocaine } & \multicolumn{2}{|c|}{ Povidone iodine } & \\
\hline & & $n$ & $\%$ & $n$ & $\%$ & \\
\hline \multirow{2}{*}{ Pruritus } & Yes & 2 & 16.7 & 1 & 6.7 & \multirow{2}{*}{0.569} \\
\hline & No & 10 & 83.3 & 14 & 93.3 & \\
\hline \multirow{2}{*}{ Ear discharge } & Yes & 1 & 8.3 & 1 & 6.7 & \multirow{2}{*}{1.000} \\
\hline & No & 11 & 91.7 & 14 & 93.3 & \\
\hline \multirow{2}{*}{ Earfullness } & Yes & 2 & 16.7 & 1 & 6.7 & \multirow{2}{*}{0.569} \\
\hline & No & 10 & 83.3 & 14 & 93.3 & \\
\hline \multirow{2}{*}{ Otalgia } & Yes & - & - & 2 & 13.3 & \multirow{2}{*}{0.487} \\
\hline & No & 12 & 100 & 13 & 86.7 & \\
\hline \multirow{2}{*}{ Tinnitus } & Yes & 1 & 8.3 & - & - & \multirow{2}{*}{0.444} \\
\hline & No & 11 & 91.7 & 15 & 100 & \\
\hline \multirow{2}{*}{ Deafness } & Yes & 1 & 8.3 & - & - & \multirow{2}{*}{0.444} \\
\hline & No & 11 & 91.7 & 15 & 100 & \\
\hline
\end{tabular}


Table 5. Sign resolution with povidone-iodine and clotrimazole (after Philip et al. 2018)

\begin{tabular}{|c|c|c|c|c|c|c|}
\hline \multirow{3}{*}{ Variables } & & \multicolumn{4}{|c|}{ Drug } & \multirow{3}{*}{$P$ value } \\
\hline & & \multicolumn{2}{|c|}{ Clotrimazole + lignocaine } & \multicolumn{2}{|c|}{ Povidone iodine } & \\
\hline & & $n$ & $\%$ & $n$ & $\%$ & \\
\hline \multirow{2}{*}{ Tragal tenderness } & Yes & - & - & - & - & \multirow{2}{*}{-} \\
\hline & No & 12 & 100 & 15 & 100 & \\
\hline \multirow{2}{*}{$\begin{array}{l}\text { Cartilaginous canal } \\
\text { wall erythema }\end{array}$} & Yes & 2 & 16.7 & - & - & \multirow{2}{*}{0.188} \\
\hline & No & 10 & 83.3 & 15 & 100 & \\
\hline \multirow{2}{*}{$\begin{array}{l}\text { Cartilaginous canal } \\
\text { wall edema }\end{array}$} & Yes & 1 & 8.3 & - & - & \multirow{2}{*}{0.444} \\
\hline & No & 11 & 91.7 & 15 & 100 & \\
\hline \multirow{2}{*}{$\begin{array}{l}\text { Bony canal } \\
\text { wall erythema }\end{array}$} & Yes & 1 & 8.3 & 1 & 6.7 & \multirow{2}{*}{1.000} \\
\hline & No & 11 & 91.7 & 14 & 93.3 & \\
\hline \multirow{2}{*}{$\begin{array}{l}\text { Bony canal } \\
\text { wall edema }\end{array}$} & Yes & - & - & 1 & 6.7 & \multirow{2}{*}{1.000} \\
\hline & No & 12 & 100 & 14 & 93.3 & \\
\hline \multirow{2}{*}{$\begin{array}{l}\text { Ear discharge } \\
\text { in the canal }\end{array}$} & Yes & - & - & - & - & \multirow{2}{*}{-} \\
\hline & No & 12 & 100 & 15 & 100 & \\
\hline \multirow{2}{*}{$\begin{array}{l}\text { Tympanic } \\
\text { membrane } \\
\text { congestion }\end{array}$} & Yes & - & - & 2 & 13.3 & \multirow{2}{*}{0.487} \\
\hline & No & 12 & 100 & 13 & 86.7 & \\
\hline
\end{tabular}

On the contrary, Kumar et al. (2017) found tropical Clotrimazol as antifungal agent in case of otomycosis. They made a clinical and microbial study of otomycosis and stated that otomycosis may be refactory to treatment prescribed, and hence changed the clinician. Their aims were to identify the causal agent and to explore specific predisposing factors for the treatment. The commonest predisposing factorfor otomycosiswas trauma due to self cleaning and water entering into the ear. Common presentation was itching of ear and ear ache. Commonest organism isolated in the experiment was A. niger (Table 6). An important report given by Kumar et al. (2017) was that presence of high pH of the ear canal to alkaline side which helped the growth of fungi. Their observation was in accordance with the study of Mugliston and Donoghue (1985). However, all these studies suggest that early diagnosis, prompt treatment and tropical antifungal therapy along with proper aural toilet may result satisfactory cure in otomycosis.Along with fungal isolates major bacterial isolates were reported by Kulal et al. (2017) which included S. aureus and Psedomonas spp. These pathogenic bacteria were sensitive to routinely used antibiotics. The antibiotic susceptibility pattern of bacterial isolates is shown in Table 7 as reported by Kulal et al. (2017). The commonest bacterial isolate $S$. aureus was sensitive to Azithromycin, Ciprofloxacin and Gentamycin. Pseudomonas spp. was mostly sensitive to Ceftazidine and Amikacin. On the other hand Klebsiella spp. was sensitive to Gentamycin in most instances and few other isolates were sensitive to Amikacin. 
Table 6. Fungus isolated (after Kumar et al. 2017)

\begin{tabular}{|c|c|c|}
\hline Fungus isolated & No. of cases & Percentage \\
\hline Aspergillus flavus & 3 & $3 \%$ \\
\hline A. fumigatus & 20 & $20 \%$ \\
\hline A. niger & 58 & $58 \%$ \\
\hline Candida albicans & 8 & $8 \%$ \\
\hline Penicillium spp. & 5 & $5 \%$ \\
\hline Mucor spp. & 5 & $5 \%$ \\
\hline Pseudoalleschia boyde & 1 & $1 \%$ \\
\hline Total & 100 & $100 \%$ \\
\hline
\end{tabular}

Table 7. Antibiotic susceptibility pattern of bacterial isolates from the study group (after Kulal et al. 2018)

\begin{tabular}{lccccccccccc}
\hline & \multicolumn{10}{c}{ Antibiotics } \\
\cline { 2 - 11 } & G & Ak & Cx & A & Cp & Az & Ac & Sp & Co & Cd & Ce \\
\hline Staphylococcus aureus (21) & 10 & & 09 & 07 & 14 & 15 & & & & & \\
\hline Pseudomonas spp. (20) & & 10 & & & & & 04 & 14 & 05 & 16 & 05 \\
\hline CONS (14) & 08 & & 07 & 06 & 09 & 09 & & & & \\
\hline Klebsiella spp. (7) & 06 & & & & 02 & & 02 & 04 & 04 & & 04 \\
\hline Escherichia coli (3) & & 03 & & & 02 & 02 & 02 & 02 & & 02 \\
\hline Proteus spp. (3) & & 02 & & & 03 & & 02 & 01 & 02 & & 02 \\
\hline Enterobacter spp. (2) & & 01 & & & 02 & 01 & 01 & 02 & & 01 \\
\hline Morganella spp. (1) & & 01 & & & 01 & & 01 & & 01 & & 01 \\
\hline Citrobacter spp. (1) & & 01 & & & & & 01 & 01 & & \\
\hline
\end{tabular}

CONS: Coagulase Negative Staphylococci (The Staphylococci species which does not give positive result to coagulase test). $G=$ Gentamycin, Ak = Amikacin, $C x=$ Ciprofloxacin, $A=$ Ampicillin, $C p=$ Cephalaxin, $A z=$ Azithromicin, $\mathrm{Ac}=$ Amoxyclave, $\mathrm{Sp}=$ Sparfloxacin, $\mathrm{Co}=$ Cotrimoxazole, $\mathrm{Cd}=$ Clindamicin, $\mathrm{Ce}=$ Cephotaxime.

The etiological factors predisposing based otomycosis are long term use of antibiotic or steroid ear drops, use of oils, maceration of underlying skin and increase in ambient pH (Prasanna et al. 2014). Most of the Indian reports indicate itching as the major symptom among otomycosis patients (Satish et al. 2013, Chapparbandi et al. 2014, Prasad et al. 2014, Nandyal et al. 2015, Haja et al. 2015). On the other hand 
Sarvan et al. (2012), Gokale et al. (2013) and Prasanna et al. (2014) found that the ear aches as the major symptom of otomycosis. The most common fungal isolate is Aspergillus spp. followed by Candida spp. and the dry lesion due to Aspergillosis. But occurance of exudate and foul smell is indicative of bacterial etiology (Emmons et al. 1970). Candida albicans is said to be a causative agent of otomycosis (Pakshir et al. 2008). Richardson and Warnock (2003) stated that Candida can colonize on different parts of the human body, but not on the skin. But other species of Candida are normal flora of skin and they are considered as causative agents of otomycosis, the role of which is debatable according to few investigators (Mahmoudabadi 2006, Kurnatowski and Filipiak 2000). However, there are many histopathological evidence where Candida spp. are considered as the sole pathogen of otomycosis (Kaur et al. 2000, Vennewald et al. 2003, Jadhav et al. 2003) and the pathogen is considered to be mainly responsible for otomycosis in immunocompromised hosts (Viswanatha et al. 2000). For the development of otomycosis bacterial infection of auditory canal may be one of the predisposing factors where use of antibiotic steroid drops for treating external otitis may predispose fungal growth. Usually pathogenic bacteria are found sensitive to antibiotics like aminoglycosides and fluoroquinolones, when these antibiotics are used routinely.

According to Chappe et al. (2018), management of otomycosis can be challenging because of its high recurrence rate and of the limited therapeutic options. The use of a $1 \%$ voriconazole sterile solution preciously validated for treatment of eye infection was considered after insuring the absence of known ototoxic effects of the antifungal. When that a patient was advised to use the voriconazal solution daily for 14 days (3-4 times a day), the full recovery occurred at the end of otomycosis treatment without any relevant side effects. The research workers found $A$. niger as the causal agent of otomycosis. More than one year after completion of therapy, there was no recurrence. Their findings had show an interesting option for treating otomycosis. However, vis-a-vis allopathic treatment of otomycosis few literatures on flok medicine are reviewed here. A pilot study was aimed by Saniasiya et al. (2017) to determine the antifungal properties of Malaysian Aloe vera leaf extract on otomycosis species including A. niger and C. albicans. Their findings reveal that for $A$. niger, a zone of inhibition for alcohol and aqueous extract was seen for all concentrations except $3.125 \mathrm{~g} / \mathrm{ml}$. There was no zone of inhibition for both alcohol and aqueous extracts of $A$. vera leaf for C. albicans. The minimum inhibitory concentration (MIC) values of aqueous and alcohol extracts were 5.1 $\mathrm{g} / \mathrm{ml}$ and $4.4 \mathrm{~g} / \mathrm{ml}$ for $A$. niger and since no zone of inhibition was obtained for $C$. albicans the MIC was not determined. They had been able to show that the Malaysian $A$. vera has a significant antifungal effects towards A. niger. Vennewald and Klem (2010) reported that despite being a benign condition, eradication of fungal infection remains a challenge for medical practitioners specially otorhinolanyngologists, where Aspergillus and Candida spp. are the most frequently isolated fungi in case of otomycosis. However, worldwide Aloe vera species are being used in folk medicine for over 2000 years. This plant specis is reported to contain over 75 nutrients and 200 active compounds including sugar, anthraquinones, saponins, vitamins, enzymes, minerals, lignin, salicylic acid and amino acids, and other different potentially active compounds including water soluble and fat soluble vitamins, minerals, enzymes, simple/ complex polysaccharides, phenolic compounds and organic acid (Radha and Laxmipriyam 2014). An antimicrobial activity of $A$. vera was conducted by Kedarnath et al. (2013) to S. aureus, K. pneumonia, E. coli, A. niger and C. albicans and found that alcohol extracts at higher concentrations were more potent than petroleum ether 
and chloroform extracts. Another study by Mbajiuka et al. (2014) revealed that ethanol extracts of $A$. vera had water MIC compared to aqueous and methanol extracts against $E$. coli, $S$. aureus and $C$. albicans. More or less similar findings were obtained by Kahing (2011) were found to support the findings of Saniasiaya et al. (2017). So from all these experimental findings it may be said that besides of allopathic treatment naturally sourced compounds may be used to formulate new and more potent antifungal agents against otomycosis.

\section{Conclusion}

In Bangladesh otomycosis in human is neglected by most of the common people. For the management of the disease, often indigenous and alternative treatment methods are followed at house hold level or as intervened by quacks. It is confusing and controversical whether single organism is responsible for the onset of otomycosis. Confirmatory test to identify the causative agents, their successive invasion in the human ear, aggressiveness, virulence or saprophytic nature and secondary effects to other parts of the body are very much important tasks to ascertain for researchers and clinicians. Moreover, otomycotic ears are often associated with bacteria along with fungal agents. Unlike bacteria, fungi and human being are eukaryotic organism. That is why, extreme care should be taken to prescribe fungicidal medicines. Considering gender, age and occupation survey should be made frequently all over the country and clinical based treatment should be strengthened.

\section{Acknowledgment}

The authors are thankful to the authority of Shah Mukhdum Medical College, Rajshahi for granting the study leave and sincere co-operation to the first author of this research article.

\section{References}

Adhikari P, Kharel B, Ma J, Baral D, Pandey T, Rijal R and Sharma H (2008). Pattern of ontological diseases in school going children of Katmandu Vallcy. International Archives of Otorhinolaryngology, 12(40): 502-505.

Agarwal P and Devi LS (2017). Otomycosis in a rural community attending a tertiary care hospital: assessment of risk factors and identification of fungal and bacterial agents. Journal of Clinical and Diagnostic Research, 11(6): 14-18.

Ahmad YM, Mohammad AA, Rohullah D and Hossain H (2009). The prevalence of otomycosis in Kashan, Iran, during 2001-2003 Jundishapur, Undishapur. Journal of Microbiology, 2(1): 18-21.

Aneja KR, Sharma $C$ and Joshi R (2010). Fungal infection of the ear: a common problem in the north eastern part of Haryana. International Journal of Pediatric Otorhinolaryngology,74(6): 604-607.

Barati B, Okhovvat SAR, Goljanian A and Omrani MR (2011). Otomycosis in central Iran: a clinical and mycological study. Iranian Red Crescent Medical Journal,13(12): 473-876.

Chadha S, Saval A, Malhotra V and Agarwal A (2012). Prevalcnce of prevcntable ear disorders in over 15000 school children in Northern India. The Journal of Laryngology and Otology, DOI: 10.1017/S0022215112002691.

Chapparbandi RB, Kazi FN and Ali K (2014). Otomycosis: An overview in hiyderabad Karnataka region. J Evol of Med and Den Sci., 3(36): 11213-11216.

Chappe M, Vrignand S, de Gentile L, Legrand G, Lagarce F and Le Govic Y (2018). Successful treatment of a recurrent Aspergillus niger otomycosis with local application of voriconazote. J Mycol Med., 28(2): 396-398. 
Deshmukh J, Surpam R and Band A (2014). Mycological study of Aspergillus infections in otomycosis in eastern part of Maharashtra. Int J Health Sci Res., 4(10): 77-82.

Dorko F, Lenca A, Orencak M, Viragova S and Pilipcine F (2004). Otomycoses of candidal origin in eastern Slovakia. Folia Microbiol (Praha), 49(5): 601-604.

Emmons CW, Binfordcll and Utz JP (1970). Aspergillosis in Medical Mycology. Lea andFebiger. Philadelphia, p 258.

Fasunla I, Ibekwe T and Onakooya P (2008). Otomycosis in western Nigeria. Mycoses, 51(1): 67-70.

Garcia-Agndo L, P Aznar-Marin, F Galan-Sanchez and P GM Pilar (2011). Otomycosis due to filamentous fungi, Mycopathologia, 172(4): 307.

Geaney GP (1967). Tropical otomycosis. J Fournal of Laryngology and Otology, 81(9): 987-997.

Gokale SK, Suligavi SS, Baragundi M, Anushka D and Manjula R (2013). Otomycosis: A clinico mycological study. Int J Med Health Sci., 2(2): 218-223.

Haja AN, Shaik KM and Siva Subba Rao P (2015). Mycology of otomycosis in a tertiary care teaching hospital. J Res Med Den Dci., 3(1): 27-30.

Hueso Gutierrez P, Limencz Alvarez S, Gil-CarcedoSanudo E, Gil-Carcedo Garcia IM, Ramos Sanchez C and Vallejo Valdezate I (2005). A Persumprion diagnosis: otomycosis. A 451 patients study [in Spanish]. Acta Otorrinolaringol Esp., 56(5): 181-6.

Jackman A, Word R, April M and Bent J (2005). Topical antibiotic induced otomycosis. Int J Pediatr Otorhinofaryngol, 69(6): 857-60.

Jadhav VJ, Pal M and Mishra GS (2003). Etiological significance of Candida albicans in otitis externa. Mycopathologia, 156: 313315.

Jain SK and Agrawal SC (1992). Sporostatic effect of some oils against fungi causing otomycosis. Indian Journal of Medical Sciences, 46(1): 01-06.

Jaiswal SK (1990). Fungal infection of ear and its sensitivity pattern. Indian Journal of Otolaryngology, 42(1): 19-22.

Joy MI, Agarwal MK, Samant HC, Gupta OP and Sharma BM (1980). Mycological and bacteriological studies in otomycosis. Indian Journal of Otolaryngology, 32(3): 72-75.

Kaur R, Mittal N, Kakkar M, Morheshwarr AKA and Malhur D (2000). Otomycosis: A clinicomycologic study. Ear. Nose and Throat Journal, 79(8): 606-609.

Kedarnath, Kaveri KM, Chimkod VB and Paril (2013). Antimicrobial activity of Aloe vera leaf extract. Int J Pharm Tech, 4(4): 286-209.

Khaing TA (2011). Evaluation of antifungal and antioxidant activities of leaf extract of Aloe vera. World Acad Sci Eng Technol., 5: 610-612.

Kazemi A, Majidinia M, Jaafari A, Mousavi SAA, Mahmoudabadi AZ and Alikhah $\mathrm{H}$ (2015). Etiologic agents of otomycosis in the north-western area of Iran. Microbiol., 8(9): e21776.

Kulal B, Bhat KS, Meundi M and Kotigadde S (2017). A microbiological study of otomycosis. Indian J Microbiol Res., 4(1): 118-125.

Kurnatowski P and Filipiak A (2000). Otomycosis: Prevalence, clinical symptoms, therapeutic procedure. Mycoses, 44(11-12): 472-479.

Kumar R, Kumar C and Kumar S (2017). Clinical and microbial study of Otomycosis. International Journal of Medical and Health Research, 3(1): 118-119. 
Lia X, Liang Q, Chi E and Cao W (2012). Otomycosis in Shanghai: actiology, clinical features and therapy. Mycoses, 55 : 104-109.

Mahmoudabadi AZ (2006). Mycological studies in 15 cases of otomycosis. Pak J Med Sci., 22(4): 486-488.

Mgbor N and Gugnanr H (2001). Otomycosis in Nigena: treatment with mercurochiome. Mycoses, 44(9 10): 395-397.

Mgbe RA, Umana A, Adekanye and Offing M (2010). Otomycosis- A management challenge in Calabar, South-South Nigeria. The Internet Journal of Third World Medicine, 9(2): 01-05.

Mbajiuka CS, Obeagu El and Okwandu GE (2014). Antimicrobial effect of Aloe veraon some human pathogens. Int J Cur Microbio App Sci., 3(3): 1022-1028.

Mugliston TGO and Donoghue (1985). Otomycosis: A continuing problem. Journal of Laryngology and Otology, 99: 327333.

Munguia R and Daniel SJ (2008). Ototopical antifungals and otomycosis: a review. International Journal of Pediatric Otorhiholaryngology, 72(4): 453-459.

Nandyal CB, Choudhari AS and Sajjan NB (2015). A cross sectional study for clinico mycological profile of otomycosis in north Karnataka. Int J Med Health Sci., 4(1): 64-69.

Ologe FE and Nwabuisi C (2002). Treatment outcome of otomycosis in Ilorin. Nigeria. West Afr. Med., 21(1): 34-36.

Ozcan KM, Ozcan M, Karaarslan A and Karaarslan F (2003). Otomycosis in Turkey: predisposing factors, aetiology and therapy. Arvngol Otol., 117(1): 39-42.

Pakshir K, Sabayan B, Javan H and Karamifar K (2008). Mycoflora of human external auditory canal in Shiraz Southern Iran. Iranian Red Crescent Med J., 10(1): 27-29.

Philip A, Thomas R, Job A, Sundaresan VR, Anandan S and Albert RR (2013). Effectiveness of 7.5 percent povidone iodine in comparison to 1 percent Clotrimazole with Lignocaine in the treatment of otomycosis. ISRN Otolaryngology, ID 239730.

Panchal P, Pethani Patel D, Rathod S and Shah P (2013). Analysis of various fungal agents in clinically suspected cases of Otomycosis. Indian J Basic and Applied Med Res., 2(8): 865-869.

Prasanna V, Hemlata Katiyar VM and Kannan I (2014). Study of etiological factors, mycological profile and treatment outcome of otomycosis. Int J Medical Res Rev., 2(4): 355-360.

Paulose KO, Al Khalifa S, Shenoy P and Sharma RK (1989). Mycotic infection of the ear (otomycosis): A prospective study. J. Laryngol Otol., 103: 30-35.

Pontes ZB, Silva AD, Lima E, de O, Guerra M, de H, Oliveira NM, Carvalho M, de I and Guerra FS (2009). Otomycosis; A retrospecttiv study. Brazilian Journal of Otolarygology, 75(3): 367-370.

Pradhan B, Tuladha NR and Amatya RM (2003). Prevalence of otomycosis in out patient department of otolaryngology in Tribhuvan University Teaching Hospital Kathmandu, Nepal. Ann Otol Rhinol Laryngol, 112(4): 384-87.

Prasad SC, Kotigadde S, Shekhar M, Thada ND, Prabhu P, D'Souza T and Prasad KC (2014). Primary otomycosis in the Indian subcontinent: predisposing factors, microbiology, and classification. International Journal of Microbiology, Article ID 636493.

Radha MH and Laxmipriya NP (2014). Evaluation of biological properties and clinical effectiveness of Aloe vera: A systematic review. J Tradit Complement Med., 5(1): 21-26.

Richardson MD and Warnock DW (2003). Fungal infection, diagonosis and management. Blackwell Pub., pp. 153-185.

Rutt Al and Sataloff RT (2008). Aspergillus otomycosis in an immunocompromised patient. Ear Nose Throat J, 87(11): 622-3. 
Sarvan RR, Kikani KM, Mehta SJ and Joshi PJ (2012). Clinico-mycological study of otomycosis. Int J Biol Med Res., 3(4): 2469-2470.

Satish HS, Viswanatha B and Manjuladevi M (2013). A Clinical Study of otomycosis. Journal of Dental and Medical Sciences, 5(2): 57-62.

Saniasiaya J, SalimR, Mobamad I and HarunA (2017). Antifungal effect of Malaysian Aloe veraleaf extract on selected fungal species of pathogenic otomycosis species in in vitro culture medium. Oman Medical Journal, 32(1): 41-46.

Tagn HO, Seffaory T, Vrabee, Yoo D and Coker NJ (2006). Otomycosis: Clinical features and treatment implications. Otolaryngology Head and Neck Surgery, 13(5): 787-791.

Thakur SK, Singh SK, Mahato B, Singh A and Mahoto D (2019). Pattern of otological diseases in school-going children of the Sunsari district of eastern Nepal. The Internet Journal of Otorhinolaryngology, DOI: 10.5580/IJORL.25808.

Vennewald I, Schonlebe J and Klemm I (2003). Mycological and histological investigations in humans with middle ear infections. Mycoses, 46: 12-18.

Vennewald I and Klemm E (2010). Otomycosis: Diagnosis and treatment. Clin Dermatol., 28(2): 202-211.

Viswanatha B and Naseeruddin K (2011). Fungal infections of the ear in immunocompromised host: a review. Mediterrancan J I lematol Infecti Dis., 3(1): Article ID e2011003.

Viswanatha B, Sunratha D and Vijayashree MS (2012). Otomycosis in immunocompetent and immunocompromised patients: comparative study and literature review. Ear Nose Throat J., 91: 114-21.

Yavo W, Kassi RR, Kiki-Barro PC, Bamba A, Kple T, Menan El and Kone M (2004). Prevalence and risk factors for otomycosis treated in the hospital setting in Abidian (Ivory Coast) in French. Med Trop Mars., 64(1): 39-42.

Yehia MM, Al-Habib HM and Shehab NM (1990). Otomycosis: a common problem in North Iraq.Journal of Laryngology and Otology, 104(5): 387-389.

Yassin A, Maher A and Moawad MK (1978). Otomycosis: a survey in the eastern province of Saudi Arabia, Journal of Laryngology and Otology, 92(10): 869-876.

Zaror T, Rischman O, Suzuki FA and Felipe RG (1991). Otomycosis in Sao Paulo. Rev Inst Med Trop Sao Pouto, 33(3): 169-73.

(Manuscript received on October 22, 2019 and revised on December 11, 2019) 
Nipa et al. 